\title{
山岳トンネルベルトコンベヤずり出し システムの開発と覆工振動対策
}

\author{
吉富幸雄 ${ }^{1} \cdot 川$ 上純 ${ }^{2} \cdot$ 清水惠助 $^{3}$ \\ '正会員 工修 大成建設侏）土木技術部（テ163-0606 東京都新宿区西新宿1- 25- 1) \\ ${ }^{2}$ 正会員 工博 大成建設侏）土木技術研究所（テ245-0051 神奈川県横浜市戸塚区名瀬町344-1) \\ 3正会員 工博 九州工業大学 建設社会工学科（テ804-8550 福剛県北九州市戸烟区仙水町1- 1)
}

\begin{abstract}
山岳トンネルにおいて,ずり出し時の環境改善は大きな課題の一つである. 筆者はこのずり出し方式において, ダンプを用いないべルトコンベヤ方式によるずり出しシステムを開発したものである. 狭殓なトンネル空間への システム導入に当たっては, ベルトコンベヤの振動が覆エコンクリートに与える影響や掘削と併行して作業する 覆エコンクリートやインバートへの作業性が㲘念された. 本論文は, ベルトコンベヤの振動が覆工コンクリート に与える影響を調べるため振動を測定し，振動対策として施工性を考虑したベルトコンべヤの位置と支持方法を 提案したものである. さらに，これらの振動による覆エコンクリートへの影響を検討したものである.
\end{abstract}

Key Words : tunnel, muck haulage, belt conveyor,crusher, work environment

1. はじめに

近年，山岳工法のトンネル工事においては，社会的 に塵肺訴訟が大きな問題としてクローズアップされて おり，施工時の環境改善が大きな課題になっている.

特にずり出し時の作業環境は悪く,ダンプの排出ガス や走行による粉じんにより劣悪な環境で作業が行われ ているのが現状である.

従来, トンネルのずり出し方式は, トンネル延長が 長くなると換気を考慮し内燃機関を使わないレール方 式が一般的に採用されていた．しかし近年，掘削工法 にNATMが多く採用されるようになり，施工性に優 れたタイヤ方式が多く採用されている。

タイヤ方式においては, 車両に黒煙除去装置や排出 ガスの浄化装置を取り付ける方法, また換気容量の増 加や集塵機を用いて環境改善が行われているが, ダン プが走る以上, 排出ガス, 粉じんが坑内全域で発生す るため, 抜本的な環境改善にならないのが現状である. このようなずり出し時の環境を改善するためには, 粉 じんの発生しないずり出し方法の開発が不可欠と考え, ベルトコンベヤ方式によるずり出しシステム（以下， ベルトコンベヤずり出しシステムという)を開発した. ベルトコンベヤずり出しシステムは, 近年T BMで
の掘削に採用されているが, 山岳工法のトンネル工事 では採用がなかった，それは, 山岳工法のトンネル掘 削では掘削だけでなく, 覆工コンクリート, インバー トも併行して施工されるため，各作業に支障を与えず にベルトコンベヤを配置する方法が難しかったからで ある. また狭盂なトンネル空間へのシステム導入に当 たっては, ベルトコンべヤの覆工コンクリートへの振 動の影響も問題と考えられた.

本論文では, ベルトコンベヤの振動が覆工コンクリ 一トに与える影響を調べるため, 振動源を精査し振動 測定を実施し，振動対策として施工性を考慮したベル トコンベヤの位置及び支持方法を提案したものである. さらに, これらの振動による覆工コンクリートへの影 響も合わせて検討した.

\section{2. ずり出しシステムの概要および問題点}

（1）ベルトコンベヤずり出しシステムの問題点

ベルトコンベヤずり出しシステムを山岳工法の発破 掘削で採用する場合の問題点は以下の点であった。

・掘削の進行に伴いベルトコンベヤ長さを随時延長す る必要がある. 


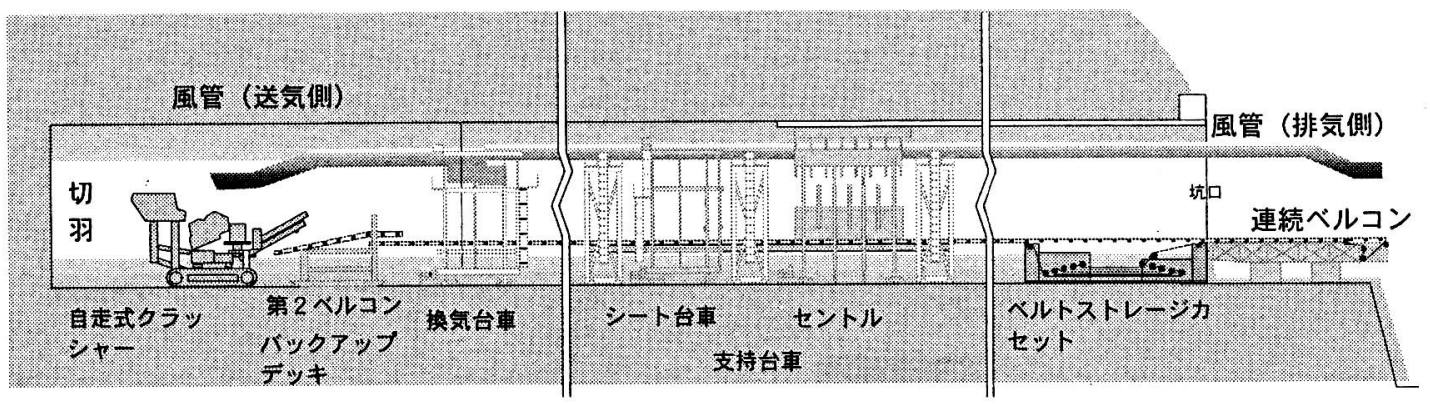

図-2 システム構成図

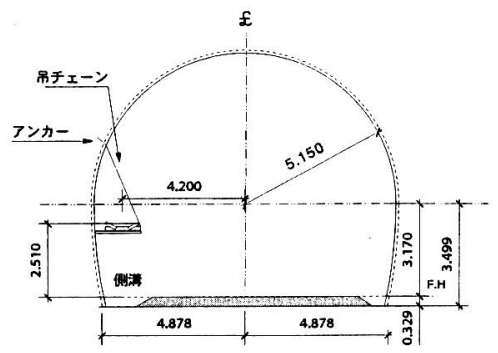

図-1 掘削断面図

・発破掘削により発生するずりの粒径は不均一で，ず りの最大粒径でベルト幅を決定するとベルト幅が広く なり，坑内の他作業に支障する。

・覆工コンクリート，インバート作業に支障せずベル トコンベヤを配置また支持する必要がある.

以上のような問題点があり, ベルトコンベヤずり出 しシステムの採用においては，ずり運搬という基本的 な能力以外にトンネル内で併行して行われている作業 に支障しないシステムの開発が必要であった.

\section{（2）ベルトコンベヤずりシステムの概要}

ベルトコンベヤずり出しシステムの適用にあたって は，図ー1 に示す新幹線の掘削断面内で検討した。

ベルトコンベヤずり出しシステムは図 - 2 に示すよ うに, 自走式クラッシャと連続ベルトコンベヤで構成 されている. 自走式クラッシャはホッパ, 振動フィー ダ, クラッシャ等を一体化し, 移動可能なクラッシャ である.

連続ベルトコンベヤはベルトストレージカセット部 にベルトをストックできる構造になっており, 切羽の 進行に合わせて随時べルトが引き出され，ベルトコン ベヤの長さが長くなるコンベヤである. ベルトはいち どに約 300m 収納可能で, ストックしたベルトが無く なるとべルトを継足し, ベルトコンベヤの長さを長く していく構造になっている. 一方, ずり出しシステム の能力は, 従来のタイヤ方式と同等の処理能力 $300 \mathrm{t} / \mathrm{h}$ とするため, ベルト幅は $600 \mathrm{~mm}$, ベルトスピードは

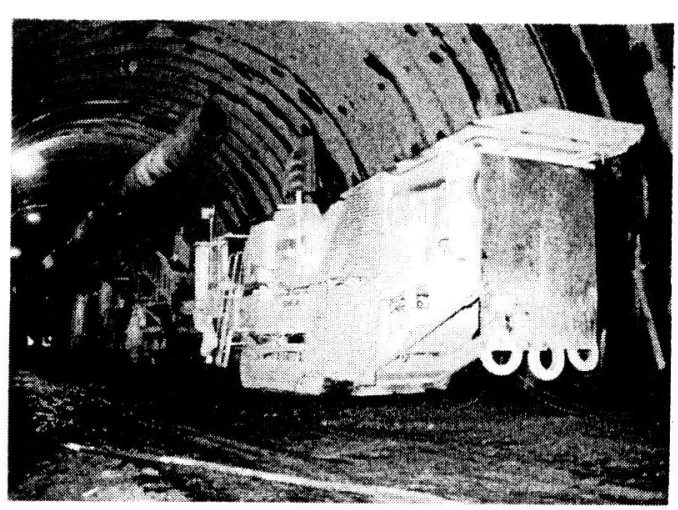

写真 -1 自走式クラッシャ
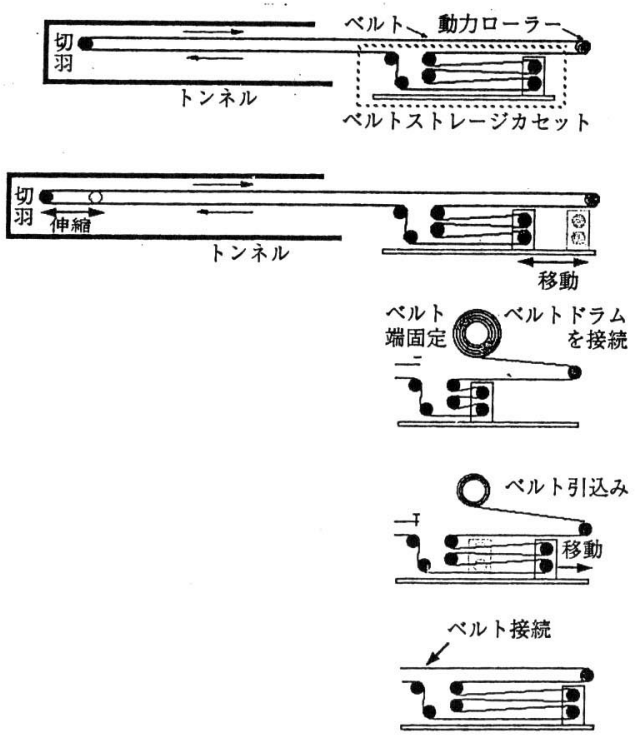

図－3＼cjkstart連続ベルトコンベヤイメージ図

168m/minで設定した. また, 切羽で発生したずりを積込 む機械はホイールローダを用い, 自走式クラッシャに直 接投入する方法を採用した. 図一3に連続ベルトコンベ ヤの延伸イメージを示す. 


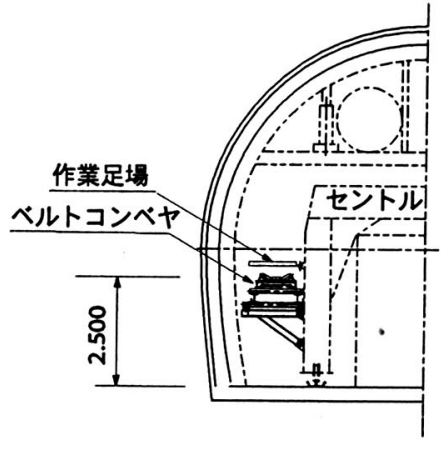

図-4 セントル部におけるベルトコンベヤ位置

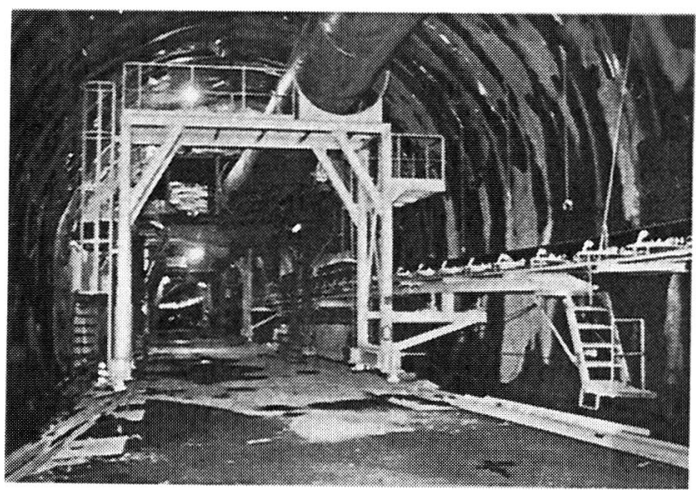

写真 - 2 移動式支持台車 (切羽側)

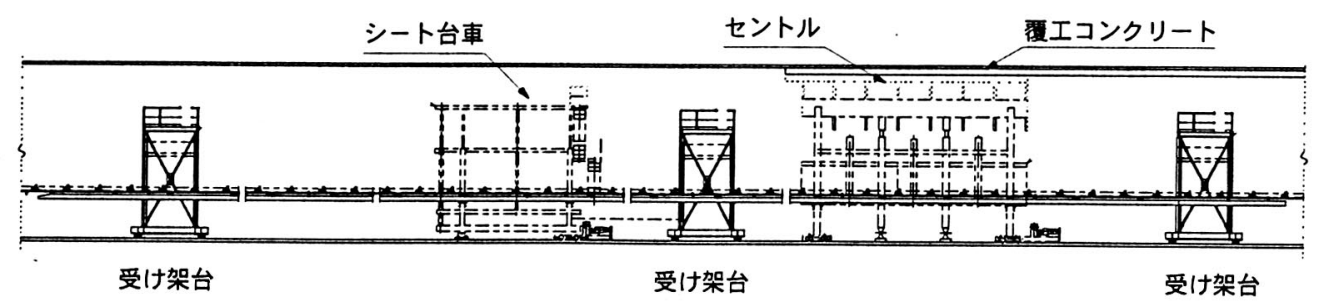

図-5 移動式支持台車

\section{3. ベルトコンベヤの位置および支持方法}

山岳工法のトンネル工事では, 掘削だけでなく覆工 コンクリート，インバートを併行して工事が進められ る. そのためずり出し以外の作業においてはべルトコ ンベヤは邪魔になるため, 出来るだけ各作業に支障し ない位置に配置する必要がある。ここでは各作業エリ アにおけるべルトコンベヤ配置を決める条件及び支持 方法について述べる.

（1）覆工作業部におけるベルトコンベヤ

\section{a) ベルトコンベヤ高さ}

覆工作業はセントルの移動, 妻部の型枠, セントル 下部の型枠やコンクリート打設等の作業が行われるが, ベルトコンベヤ通過により作業に支障を与えず, ベル トコンベヤ稼動時に作業員の安全を確保できる位置に 据付けなければならない，それら条件を考えると，路 盤より約 $2.5 \mathrm{~m}$ の高さでセントルのガントリーとワォ ールの間にベルトコンベヤを配置するのが最適と考え られる．この位置はワォールをサポートするパイプサ プートが位置するが基本的には作業に支障なく，また セントル作業足場の下部に位置し，ベルトコンベヤの 稼動時も覆工作業員の安全を確保できると考えで決
定した. 図-4にベルトコンベヤの据付け位置を示す.

\section{b ）覆工作業部のベルトコンベヤ支持}

覆工作業部は防水シート張りおよび覆工コンクリー トが行われている区間で, ベルトコンベヤの支持方法 には以下の条件を満たす必要がある.

・掘削面には防水シートが張られるため, 掘削面か吊 る方式以外でベルトコンベヤを支持する必要がある。 ・防水シート張り台車やセントルは掘削作業に関係な く前後に移動可能である.

・覆工の作業場所は順次移動するため, ベルトコンベ ヤ支持も随時受け代える必要がある.

以上の条件を満足する機構として移動式支持台車を 製作した．移動式支持台車を図一5に示寸。

移動式支持台車は 3 台の受け架台とベルトコンベヤ を支持するビームから構成されている．移動は先頭の 受け架台と後尾の架台に取り付けられたモーターの駆 動によって行う。中間の受け架台はシート張り台車よ りワイヤで牽引される構造となっており，ビームとは 固定されてなく，ローラを介してビームを支持する構 造になっている.

シート張り台車は先頭部の架台と中間の架台の間に 位置し，その間を移動可能になっている. 


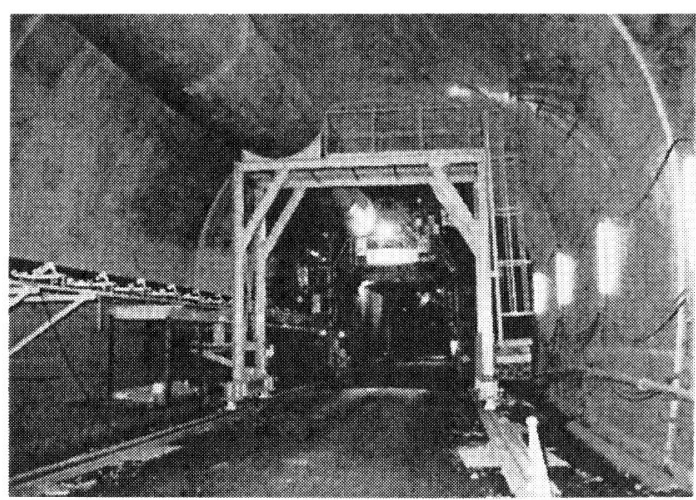

写真 - 3 移動式支持台車 (坑口側)

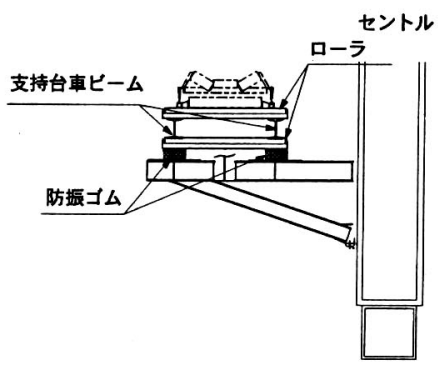

図-6 セントル部の支持方法

また，ビームの撓みを抑えるため，シート張り台車は ローラを介してビームを支持する構造になっている.

一方, 中間の架台と後尾の架台の間にはセントルが 位置し，その間をセントルは前後に移動可能になって いる. セントルはシート張り台車同様ビームの撓みを 抑えるため，防振ゴムを取付けたローラを介して支持 する構造になっている．図－6ににセントル部の支持構 造を示す。

この移動式支持台車により，ベルトコンベヤを支持 しながら, 防水シートの台車の移動やセントルの移動 が可能になり, ベルトコンベヤの組立てや解体をする ことなく連続的に支持することが可能となった。

\section{（2）掘削部のベルトコンベヤ}

掘削部では, 切羽からの湧水処理や路盤の維持のた め, 断面両サイドに側溝を設ける場合が多く, 路盤か らのベルトコンベヤ支持は邪魔になる. また掘削部は， 重機の離合が激しく低い位置にベルトコンベヤを配置 すると作業に支障する．あまり高い位置に配置すると ベルトコンベヤからの落石があった場合に危険である ため, 覆工と同様に路盤より約 $2.5 \mathrm{~m}$ の位置に配置した。 一方ベルトコンベヤの固定方法は, 延長時容易に支持 できる構造にする必要があるため, 掘削側面より片側 チェーンで吊り, 他方はアンカーで固定する構造と

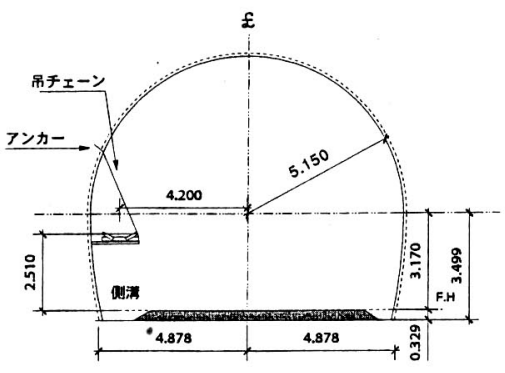

図-7 掘削部付近の側壁部のベルトコンベヤ支持方法

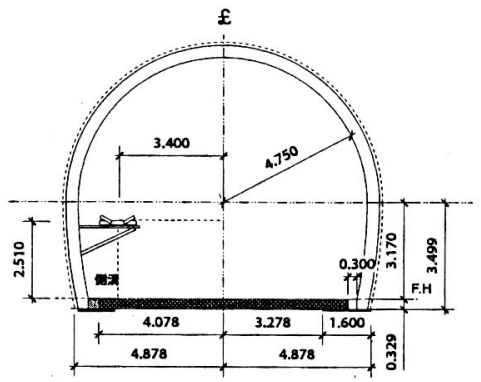

図-8 覆工完了部のベルトコンベヤ支持方法

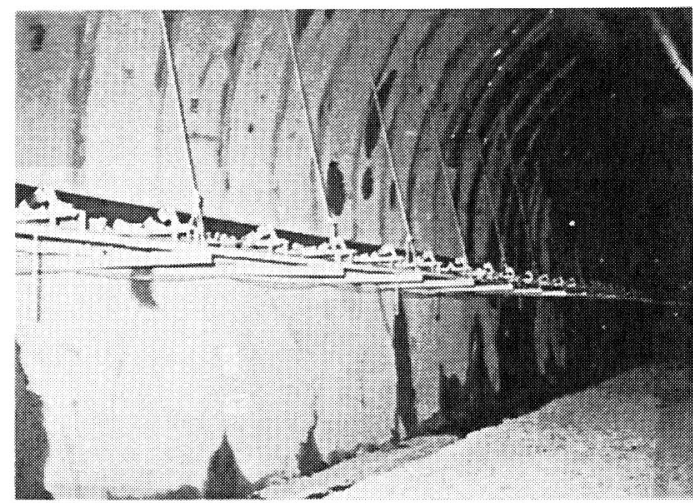

写真 - 4 掘削部付近の側壁部のベルトコンベヤ支持方法

した. 図-7 に掘削部のベルトコンベヤ支持構造を示 す.

（3）覆工完了部のベルトコンベヤ

覆工完了部においては, 通行車両や路盤の維持管理 のために設けられる仮設側溝の維持管理及びインバー 卜施工などに支障を与えない位置にベルトコンべヤを 配置しなければいけない，そのため覆工作業部と同様 に路盤より約 $2.5 \mathrm{~m}$ の高さに配置した。

一方, ベルトコンベヤの支持方法は覆工コンクリー ト側面よりブラケットで支持する構造とした. 
表-1 ベルトコンベヤ振動による覆工コンクリー トへの影響

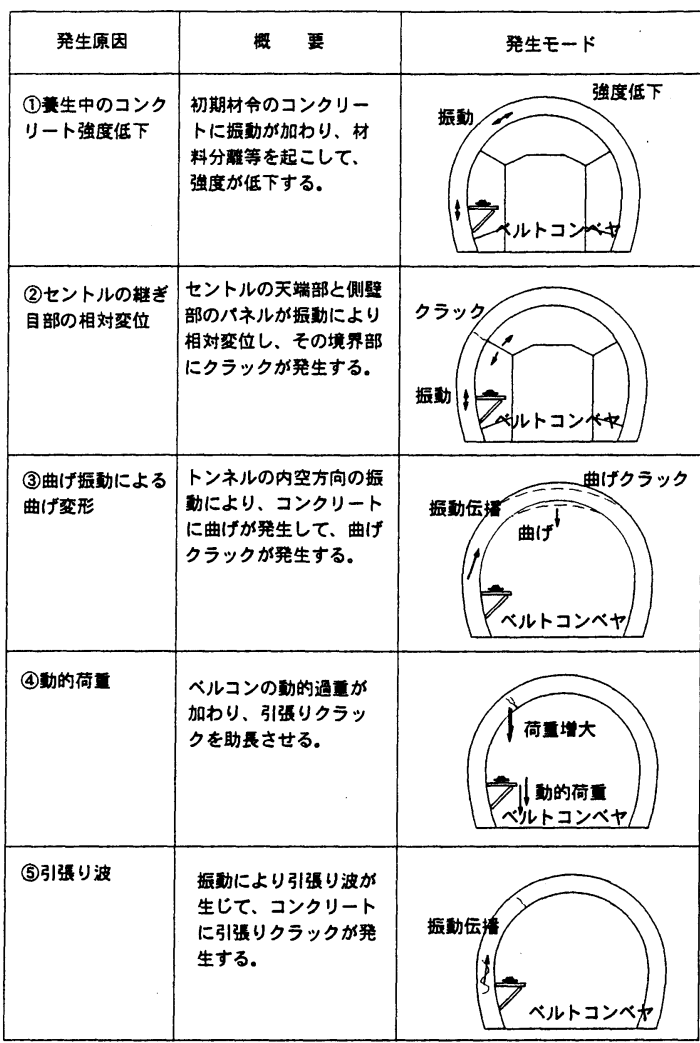

4. ベルトコンベヤの振動による覆エコンクリー トへの影響

\section{(1) 概要}

ベルトコンベヤを支持する構造は，覆工完了部では ブラケットにより覆エコンクリートで支持し，セント ル部ではベルトコンベヤの振動が弱齢時のコンクリー 卜強度発現に悪影響が出ることを防ぐために防振ゴム を介した方法を採用した。

ここでは，実際にベルトコンベヤ稼働時の覆工コン クリートおよびセントルの振動を測定し，振動の発生 状況とそのコンクリートへの影響について検討を行っ た.

\section{（2）振動による覆エコンクリートへの影䉕}

ベルトコンベヤの振動による覆工コンクリートへの 影響としては，表- 1 に示寸 5 項目が考えられる.

\section{（3）検討項目}

表 - 1 の覆エコンクリートへの影響を検討するため, 振動測定は，表－2 に示す 4 項目について行った.
表 - 2 振動の検討項目と測定内容

\begin{tabular}{|c|c|}
\hline 検討項目 & 測定内容 \\
\hline 振動発生源の検 & ベルトコンベヤ駆動部および中間ブースタ \\
\hline & \begin{tabular}{|l|} 
- からの距離とブラケットの振動の振幅の \\
関係を測定
\end{tabular} \\
\hline $\begin{array}{l}\text { ベルトコンベヤ } \\
\text { の動的荷重 }\end{array}$ & $\begin{array}{l}\text { 動的荷重を測定するために, ベルトコンべ } \\
\text { ヤ架台にひずみゲージを貼り，静的荷重と } \\
\text { 比較して動的荷重を測定 }\end{array}$ \\
\hline 覆エコンクリー & 覆工コンクリートに振動計を取り付けて振 \\
\hline $\begin{array}{l}\text { 卜の振動モー } \\
\text { と共振の有無 }\end{array}$ & 動測定を行い，振動モードおよび最大值を \\
\hline セントルの振動 & セントルの各部で振動を測定し，最大值を \\
\hline $\begin{array}{l}\text { 測定と防振ゴム } \\
\text { の効果 }\end{array}$ & 測定. また，防振ゴムおよび支持架台での \\
\hline
\end{tabular}

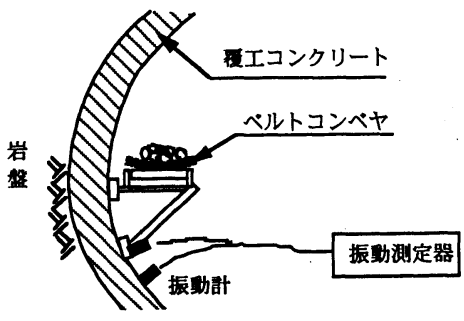

图-9 ブラケットでの振動測定位置

（4）ベルトコンベヤの振動発生源について

a) 測定方法

ベルトコンベヤの振動は, ベルトコンベヤの駆動部 からに発生するもの, およびベルトコンベヤのローラ を掘削ずりが乗り越える時に発生するものが考えられ る. そこで, ベルトコンベヤの振動発生源を検討する ために，駆動部からの距離と振動の振幅の関係につい て測定を行った。

ベルトコンベヤの駆動部は，トンネル坑口に設置し てある. ベルトコンベヤは，駆動部から $50 \mathrm{~m}$ 間はトン ネルの底盤に支持され，それ以降はブラケットにより 覆エコンクリートに支持されている．また，坑口から $1600 \mathrm{~m}$ の位置には中間ブースターが設置されている. なお，中間ブースターの前後 $300 \mathrm{~m}$ 間では，振動の伝 播をより低減するために，ブラケットの脚部プレート と覆エコンクリートの間には，厚さ $2 \mathrm{~mm}$ のゴムを挟 んである.

振動測定は，掘削ずりの搬出中に，図-9 に示すブ ラケットの脚部プレートとその $2 \mathrm{~cm}$ 横の覆工コンクリ ートで行った。 測定器は, 携帯型振動計 VM-61（リ オン社製）を使用した。

b) 測定結果

図ー10に駆動部および中間ブースターからの距離 


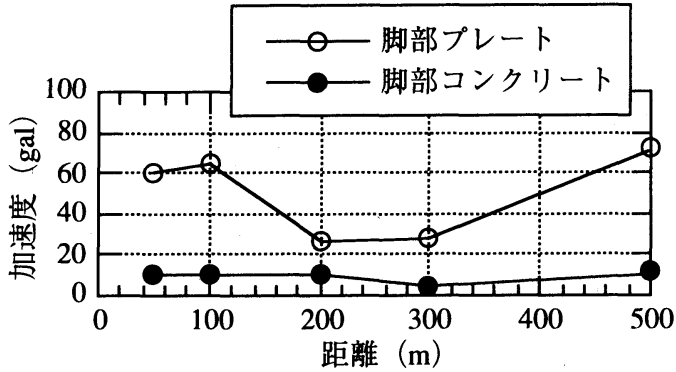

（a）駆動部からの距離と加速度の関係

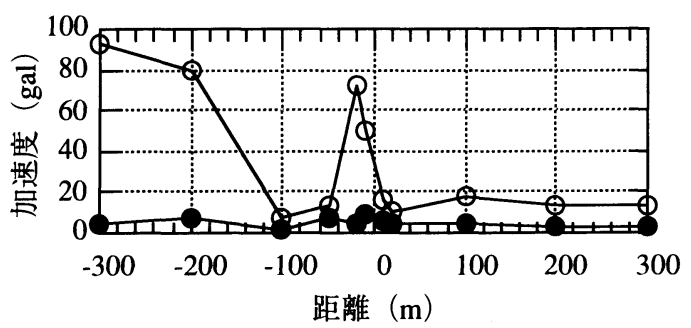

（b）中間ブースターからの距離と加速度の関係

図-10 ベルトコンベヤの駆動部および中間ブースターからの距離と加速度の関係

と加速度の関係を示す. 脚部プレートの加速度は 10 70gal であり，その横の覆工コンクリートの加速度は， 脚部プレートをコンクリートに固定している部分で 5 -12gal, ゴムを挟んである部分で 3ー9gal であり，ゴ ムを挟むことにより，覆工コンクリートの振動は $30 \%$ 程度低隇している。

図-10から分かるように, ベルトコンベヤの駆動部 および中間ブースターからの距離と振幅との相関は見 られないため, ベルトコンベヤの走行およびベルトコ ンべヤのローラを掘削ずりが乗り越える時に振動が発 生していると考えられる.

なお, 脚部プレートで加速度が 100gal 近くと大きく なっている部分があるが，これはプレートが斜めにな っていてプレートの一部しかコンクリートに接してい なかったり，固定用のボルトの一部が緩んでいる等の 固定度がやや緩かった箇所である. しかし，その部分 でも覆工コンクリートの振動は大きくなっておらず, ブラケットの固定度は覆工コンクリートへの振動伝播 に対しては影響していないことが分かる.

\section{（5） ベルトコンベヤの動的荷重}

\section{a) 測定方法}

ベルトコンベヤの振動が覆エコンクリートに与える 動的荷重を求めるために, 図-11に示すように, ベル トコンベヤのブラケットの基部にひずみゲージを貼り， 掘削ずり搬出時の動的ひずみを測定した．また, ベル トコンベヤに静的荷重 (人間) を加えた場合のひずみ を測定し, 両者の比較からべルトコンベヤの動的荷重 を算定した。

b) 測定結果

図-12に $700 \mathrm{~N}$ の静的荷重時とベルトコンベヤ稼働 時のひずみ測定結果を示す．両者を比較すると， 700 $\mathrm{N}$ 静的荷重時のひずみ $37.47 \mu$ に対し,ベルトコンベヤ 稼働時のひずみ $48.77 \mu$ で動的荷重は $910 \mathrm{~N}$ (実効値 230N）と考えられ，覆工コンクリートに悪影響を与え るような動的荷重は発生していないことが分かる.

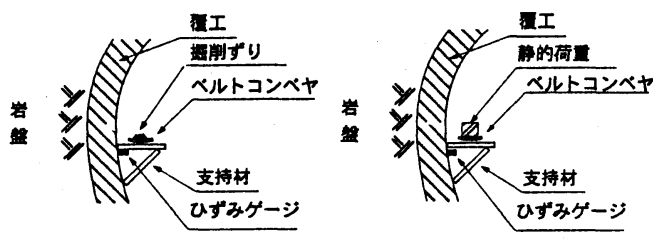

ベルトコンベヤの稼動時＼cjkstart静的荷重

図-11 ベルトコンベヤの動的荷重の測定方法

$700 \mathrm{~N}$ 静的荷重時
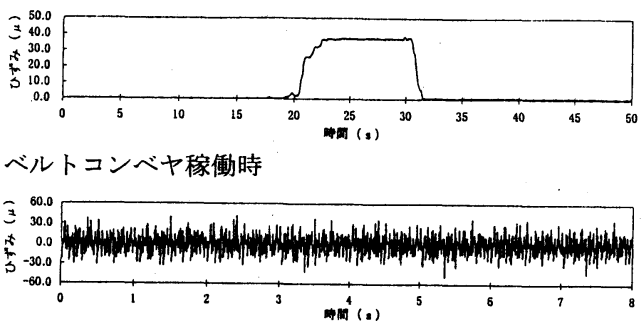

図-12 700N静的荷重時とベルトコンベヤ 稼働時のひずみ測定結果

（6）覆エコンクリート部における振動モードの検討 a) 測定方法

ベルトコンベヤの振動により, 覆工コンクリート部 が共振を起して振動が増幅しているかどうかを検討す るために，覆工コンクリート部に振動計を取り付けて 同時測定を行い，振動モードおよび最大值を測定した。 測定位置を図-13に示す. 図中の矢印は，振動の測 定方向である. 振動モードを検討するために, 測定は 内空方向 (R 方向) を主に行い, ベルトコンベヤが取 り付けてある左側および天端ではトンネル周方向（ $\theta$ 方向）の測定も行った．振動計は，振動技研社製の STP-100を使用し，加速度および変位の測定を行った。 


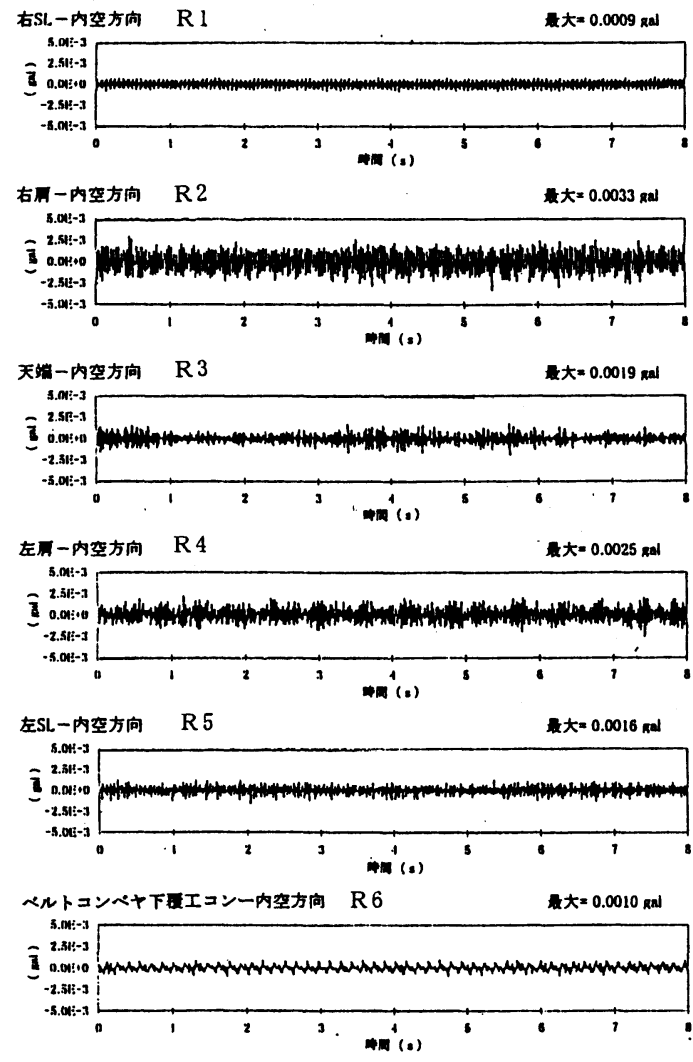

(a ) 加速度波形

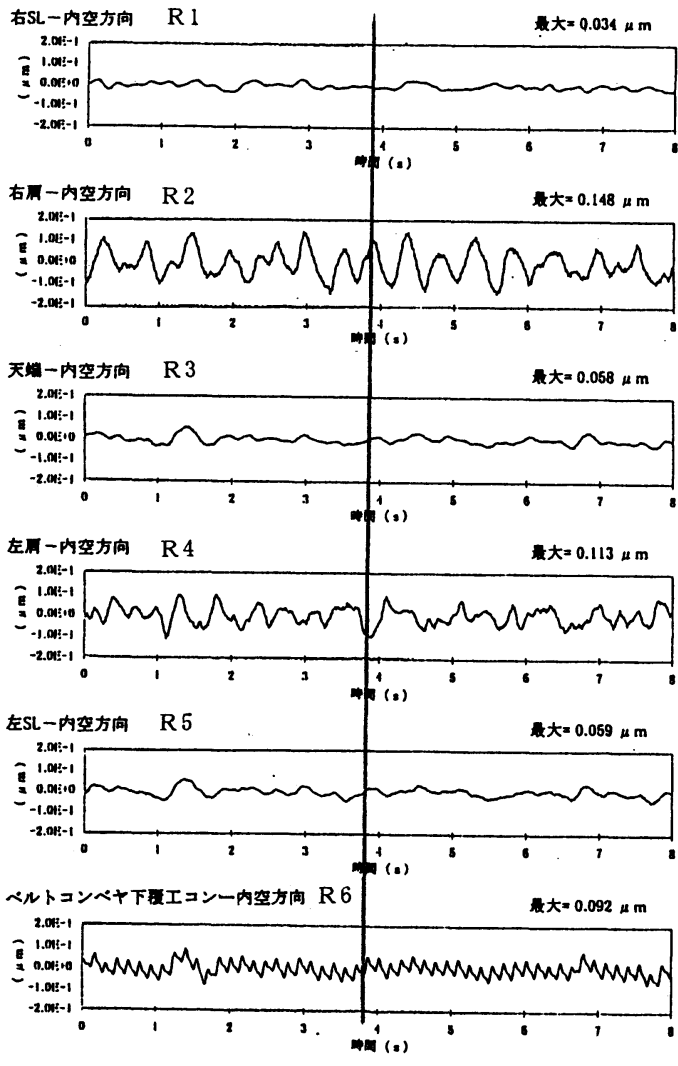

（b）変位波形

図ー 14 覆エコンクリートの振動波形

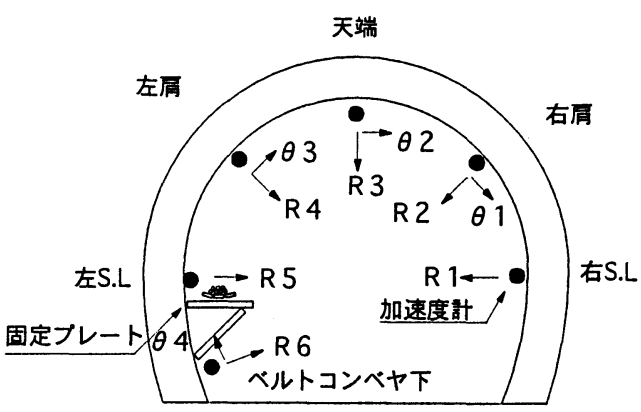

図-13 覆工コンクリート部における振動測定の位置

\section{b) 測定結果}

ベルトコンベヤ稼働時の加速度および変位波形の例 を図－14に示す.加速度波形の卓越振動数は $30-40 \mathrm{~Hz}$ であり，変位波形での卓越振動数は 1-4Hzである.

図-14の変位波形に直線で示した時刻での振動の 位相では, 天端は変化が少なく, 右肩と左肩は逆位相 で振動している振動モードが見られる。
各測定時の最大値は表-3 のようになっており, 最 大振幅は右肩部で加速度で $0.003 \mathrm{gal}$, 変位で $0.15 \mu \mathrm{m}$ 以下と小さい值となっており，共振による増幅は認ぬ， られない. なお, ベルトコンベヤ稼働時の振幅は, 停 止時の 1.5 倍程度である.

ベルトコンベヤ下の測定位置はブラケットの固定プ レートから $2 \mathrm{~m}$ 離れた位置にある. 固定プレート近傍 (左S.L.) では数 gal 程度の振幅であったが, $2 \mathrm{~m}$ 離 れると 0.001 gal と急激に減衰しており, 覆工の振動は ベルトコンベヤを固定しているブラケットの極く近傍 に限られることが分かる.

\section{c）振動モードとその影䇾の検討}

測定結果によると，覆工コンクリートの振動による 変形は, 図-15のように天端があまり動かず, 右肩と 左肩が逆位相で変形するモードが主となっていた.こ の変形モードを覆工の天端からスプリングラインまで を図－15のように梁にモデル化し，その梁に等分布荷 重が作用するとして, コンクリートに発生する応力を 算定する. 
表 -3 各測定点の最大振幅

\begin{tabular}{|c|c|c|c|c|c|}
\hline \multirow[b]{2}{*}{ 測定点 } & \multirow[b]{2}{*}{ 方向 } & \multicolumn{2}{|c|}{$\begin{array}{l}\text { ベルトコンベヤ } \\
\text { 停止時 }\end{array}$} & \multicolumn{2}{|c|}{$\begin{array}{c}\text { ベルトコンベヤ } \\
\text { 稼働時 }\end{array}$} \\
\hline & & $\begin{array}{c}\text { 加速度 } \\
\text { (gal) }\end{array}$ & $\begin{array}{l}\text { 変位 } \\
(\mu \mathrm{m})\end{array}$ & $\begin{array}{c}\text { 加速度 } \\
\text { (gal) }\end{array}$ & $\begin{array}{l}\text { 変位 } \\
(\mu \mathrm{m})\end{array}$ \\
\hline 右S.L & $\mathrm{R} 1$ & 0.0008 & 0.047 & 0.0009 & 0.034 \\
\hline 右肩 & $\mathrm{R} 2$ & 0.0021 & 0.098 & 0.0033 & 0.148 \\
\hline \multirow[t]{2}{*}{ 天端 } & R3 & 0.0003 & 0.047 & 0.0019 & 0.058 \\
\hline & $\theta 2$ & 0.0002 & 0.057 & 0.0017 & 0.055 \\
\hline \multirow[t]{2}{*}{ 左肩 } & $\mathrm{R} 4$ & 0.0021 & 0.095 & 0.0025 & 0.113 \\
\hline & $\theta 3$ & 0.0013 & 0.052 & 0.0014 & 0.057 \\
\hline 左 S.L. & R5 & 0.0017 & 0.053 & 0.0016 & 0.059 \\
\hline ペルトコ & R6 & 0.0009 & 0.081 & 0.0010 & 0.092 \\
\hline ンベヤ下 & $\theta 4$ & 0.0009 & 0.088 & 0.0010 & 0.088 \\
\hline
\end{tabular}

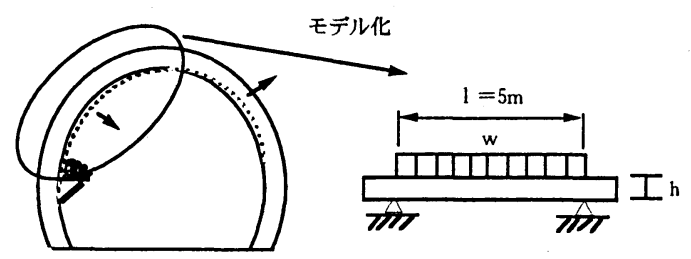

図-15 覆エコンクリート部における 振動モードのモデル化

梁の縁応力の最大值 $\sigma_{\text {max }}$ と最大変位 $\mathrm{y}_{\text {max }}$ の関係は, 以下の式で表される.ここで, $\mathrm{h}$ は梁の高さ, $\mathrm{E}$ はコ ンクリートのヤング率, 1は梁の長さである.

$$
\sigma_{\max }=\frac{24 \mathrm{hE}}{5 \mathrm{l}^{2}} \mathrm{y}_{\max }
$$

式(1)に $\mathrm{l}=5 \mathrm{~m}, \mathrm{~h}=30 \mathrm{~cm}, \mathrm{E}=25750 \mathrm{~N} / \mathrm{mm}^{2}$ および $\mathrm{y}_{\max }$ として測定された最大変位 $2.8 \times 10^{-4} \mathrm{~mm}$ を代入すると， $\sigma_{\max }=4.15 \times 10^{-4} \mathrm{~N} / \mathrm{mm}^{2}$ となる. このように, 振動によ り発生する曲げ応力は非常に小さく, 覆工には影響が ないことが分かる.

以上の検討は，硬化後のフレッシュコンクリートに 対するものであり，弱材令時のコンクリートに対して 以下に検討する. 梁の曲げ変位 $\mathrm{y}_{\text {max }}$ は, 外力が一定な らば材令 $\mathrm{t}$ 日のヤング率 $\mathrm{E}(\mathrm{t})$ に反比例する. また, 式(1) から分かるように, 梁の応力 $\sigma_{\text {max }}(\mathrm{t})$ は $\mathrm{E}(\mathrm{t})$ および $\mathrm{y}_{\text {max }}(\mathrm{t})$ に比例するので, $\sigma_{\text {max }}(t)$ は材令に関わらず一定となる.

今, 材令 $\mathrm{t}$ 日のフレッシュコンクリートの引張強度 $\mathrm{f}_{\mathrm{t}}(\mathrm{t})$ とヤング率 $\mathrm{E}(\mathrm{t})$ を, 材令 $\mathrm{t}$ 日の圧縮強度 $\mathrm{f}_{\mathrm{c}} \mathrm{c}_{\mathrm{c}}(\mathrm{t})$ の関数
表-4 各材令時のコンクリートの物性値と

振動による発生応力, 変位

\begin{tabular}{|c|c|c|c|c|c|}
\hline $\begin{array}{c}\text { 材令 } \\
\mathrm{t} \\
\text { (日) }\end{array}$ & $\begin{array}{c}\text { 圧縮強度 } \\
\mathrm{f}^{\prime} \mathrm{c}(\mathrm{t}) \\
\left(\mathrm{N} / \mathrm{mm}^{2}\right)\end{array}$ & $\begin{array}{c}\text { 弓張強度 } \\
\mathrm{f}_{\mathrm{f}}(\mathrm{t}) \\
\left(\mathrm{N} / \mathrm{mm}^{2}\right)\end{array}$ & $\begin{array}{c}\text { ヤング率 } \\
\mathrm{E}(\mathrm{t}) \\
\left(\mathrm{N} / \mathrm{mm}^{2}\right)\end{array}$ & $\begin{array}{l}\text { 発生応力 } \\
\sigma_{\max } \\
\left(\mathrm{N} / \mathrm{mm}^{2}\right)\end{array}$ & $\begin{array}{c}\text { 発生変位 } \\
\mathrm{y}_{\max } \\
(\mathrm{mm})\end{array}$ \\
\hline 1 & 5.5 & 0.82 & 11000 & \multirow{6}{*}{$4.15 \times 10^{4}$} & $6.5 \times 10^{4}$ \\
\hline 2 & 9.38 & 1.07 & 14400 & & $5.0 \times 10^{4}$ \\
\hline 4 & 14.5 & 1.33 & 17800 & & $4.0 \times 10^{4}$ \\
\hline 7 & 18.8 & 1.52 & 20400 & & $3.5 \times 10^{-4}$ \\
\hline 28 & 27.0 & 1.82 & 24400 & & $3.0 \times 10^{-4}$ \\
\hline 91 & 30.0 & 1.92 & 25800 & & $2.8 \times 10^{-4}$ \\
\hline
\end{tabular}

として以下の式"で近似する.

$$
\begin{aligned}
& f_{t}(t)=0.35 \sqrt{f_{c}^{\prime}(t)} \\
& E(t)=4700 \sqrt{f_{c}^{\prime}(t)}
\end{aligned}
$$

曲げによる縁応力の最大值 $\sigma_{\text {max }}$ が, フレッシュコン クリートの引張強度 $\mathrm{f}_{\mathrm{t}}(\mathrm{t})$ に達する時の限界变位 $\mathrm{y}_{\max }$ は, 式(1)で $\sigma_{\text {max }}=\mathrm{f}_{\mathrm{f}}(\mathrm{t})$ と置き, 式(2), (3)を代入すると以下 の式となり，材令に関わらず一定になる.

$$
y_{\operatorname{maxc}}=1.55 \times 10^{-5} \frac{1^{2}}{h}
$$

式(4)に $\mathrm{l}=5 \mathrm{~m}, \mathrm{~h}=30 \mathrm{~cm}$ を代入すると $\mathrm{y}_{\operatorname{maxc}}=1.29 \mathrm{~mm}$ と なる. 表-4 にコンクリートの各材令時の物性値と振 動による発生応力および発生変位を示す。

ベルトコンベヤが覆工に固定されるのは，セントル から 2 ブロック後であるため, 早くても打設 4 日後で ある. 表 -4 から，材令 4 日のコンクリートの許容值 である引張強度は $1.33 \mathrm{~N} / \mathrm{mm}^{2}$ であり, 振動により発 生応力は $4.15 \times 10^{-4} \mathrm{~N} / \mathrm{mm}^{2}$ と非常に小さく, 弱材令時 でも振動の影響はない. なお, 表 -4 から, 材令 1 日 でも影響ないことが分かる。

\section{（7）ブラケット近傍の検討}

覆工コンクリートでは，ベルトコンベヤを支持して いるブラケットの近傍で 12gal の振動が発生していた. この振動による影響を検討する.

振動がコンクリート中を伝播する時に発生する応力 $\sigma$ は, 以下の式となる.

$$
\sigma=\sqrt{\rho \mathrm{E} / \mathrm{g} * \mathrm{~V}}
$$

ここで, $\rho$ は単位体積重量, $\mathrm{g}$ は重力加速度で V は 


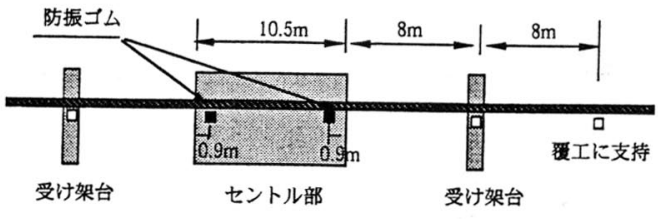

図-16 セントル部におけるベルトコンベヤ 支持図 (側面図)

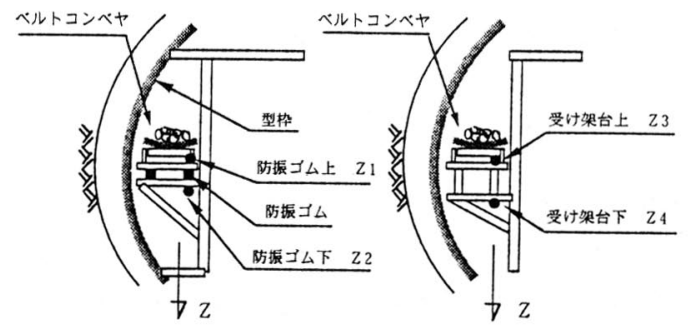

（a）セントル部での測定位置（b）受け架台での測定位置 図-16 セントル部および受け架台部 上下における測定位置

速度振幅である. 式(5)に, $\rho=2.4 \times 10^{-5} \mathrm{~N} / \mathrm{mm}^{3}, \mathrm{E}$ は 表 -4 の材令 4 日の値とする. 加速度の卓越振動数は $\mathrm{f}=30 \mathrm{~Hz}$ であるので, 速度振幅 $\mathrm{V}=12 \mathrm{gal} / 2 \pi \mathrm{f}=0.064 \mathrm{~cm} / \mathrm{s}$ を代入すると，振動により発生する応力は， $\sigma=$ $0.0042 \mathrm{~N} / \mathrm{mm}^{2}$ となる. 材令 4 日時のコンクリートの引 張強度は $1.33 \mathrm{~N} / \mathrm{mm}^{2}$ であるので, 振動によるコンクリ ートの引張りひび割れの可能性はないと言える.

\section{（8）セントル部における振動}

\section{a) 測定方法}

ベルトコンベヤは図-16 に示すように，セントルの 手前約 $8 \mathrm{~m}$ で一旦ベルトコンベヤ受け架台で受けてか ら，セントル部で防振ゴムを介して支持されている. セントル部では, この防振ゴムの効果とセントル各部 での振動を測定した，振動測定は，セントル手前のベ ルトコンベヤ受け架台, 防振ゴム部およびセントルの 3 箇所において行った.

受け架台および防振ゴムでの測定は, 図-17に示す ように, 上下方向 (Z方向) の振動を測定した. セン トルでは, 図-18 に示すように振動が大きいと考えら れるセントル脚部, 継目部および天端で測定した. 測 定方向は内空方向（R 方向）を基本とし，セントル下 部と継目部では周方向（ $\theta$ 方向）も測定した.

b) 測定結果

表 -5 に各測点での振動の最大值を示す.

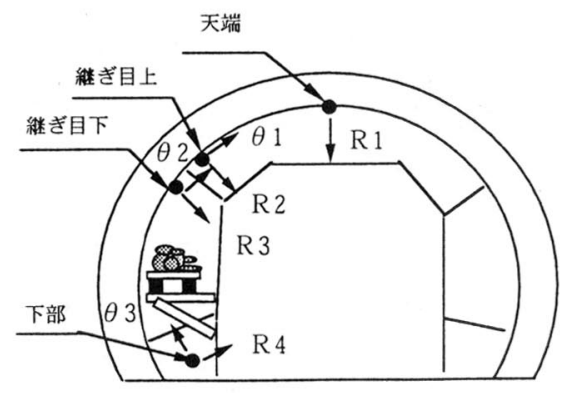

図-18 セントル部での測定位置

表-5 セントル部の各測点での振動最大值

\begin{tabular}{|c|c|c|c|c|}
\hline \multirow{2}{*}{ 測点 } & 方向 & $\begin{array}{c}\text { 加速度 } \\
(\mathrm{gal})\end{array}$ & $\begin{array}{c}\text { 速度 } \\
(\mathrm{cm} / \mathrm{s})\end{array}$ & $\begin{array}{c}\text { 変位 } \\
(\mu \mathrm{m})\end{array}$ \\
\hline 防振ゴム上 & $\mathrm{Z} 1$ & 62.2 & 0.09 & 13.7 \\
\hline 防振ゴム下 & $\mathrm{Z} 2$ & 33.3 & 0.03 & 4.77 \\
\hline 受け架台上 & $\mathrm{Z} 3$ & 26.2 & 0.17 & 23.9 \\
\hline 受け架台下 & $\mathrm{Z} 4$ & 26.8 & 0.20 & 24.9 \\
\hline セントル天端 & $\mathrm{R} 1$ & 1.02 & 0.03 & 9.46 \\
\hline セントル & $\mathrm{R} 2$ & 1.21 & 0.02 & 7.19 \\
\cline { 2 - 5 } 継目上 & $\theta 1$ & 1.52 & 0.02 & 7.10 \\
\hline セントル & $\mathrm{R} 3$ & 1.49 & 0.02 & 5.53 \\
\cline { 2 - 5 } 継目下 & $\theta 2$ & 1.34 & 0.02 & 9.80 \\
\hline \multirow{2}{*}{ セントル } & $\mathrm{R} 4$ & 1.81 & 0.03 & 11.09 \\
\cline { 2 - 5 } 脚部 & $\theta 3$ & 3.13 & 0.05 & 12.46 \\
\hline
\end{tabular}

ベルトコンベヤの受け架台や防振ゴムの上での振動は, 加速度で 20-60gal, 変位で 13ー25 $\mu \mathrm{m}$ であったが, 防振ゴムの下では, 変位は $5 \mu \mathrm{m}$ と小さくなっていた. また, セントル部の振動は加速度 1一3gal, 変位で 5 $-12 \mu \mathrm{m}$ と小さな值となっており, セントル継目部で も特に振動の増幅は認められない。

c) 防振ゴムの振動低減効果

防振ゴムの振動低减効果としては, 防振ゴムの設置 前と設置後の振動を比較して検討すべきであるが, 今 回は防振ゴム設置前の測定が行えなかったので，防振 ゴムを設置していない支持台車の受け架台の振動を防 振ゴム設置前の振動と考えて防振効果を検討する.

図 - 19 に防振ゴム下および支持台車の受け架台にお ける変位波形とそのフーリエスペクトルを示す. 防振 ゴム上および受け架台では $8.5 \mathrm{~Hz}, 18 \mathrm{~Hz}, 26.5 \mathrm{~Hz}$ に卓 越振動数があり, それぞれ 1 次, 2 次, 3 次の振動と考 えられる.防振ゴム下のフーリエでは, $8.5 \mathrm{~Hz}$ は $1 / 6$ に $18 \mathrm{~Hz}$ は $1 / 10$ に低減しており, また変位最大值も $1 / 5$ に 低減しており，防振ゴムの効果が認められる. 

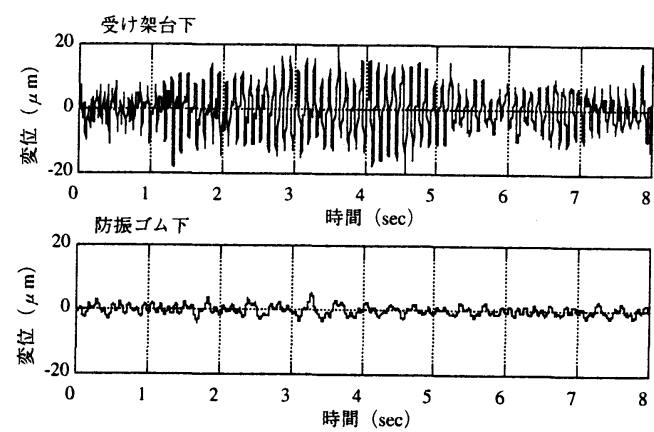

(a) 変位波形
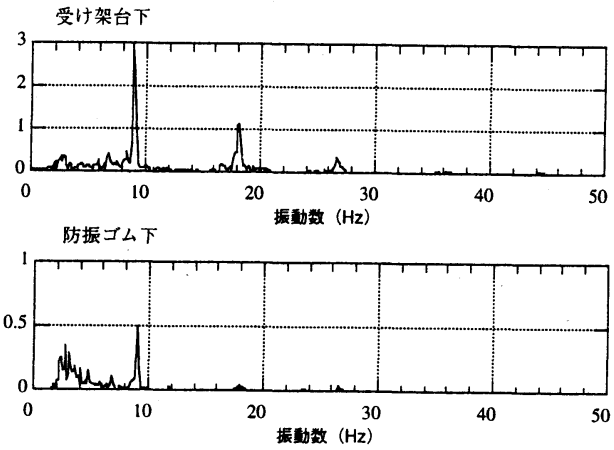

(b) フーリエスペクトル

図-19 受け架台下と防振ゴム下の变位波形とその フーリエスペクトル

\section{d）コンクリートへの影響}

養生中のコンクリートに対する振動の影響に関する 既往の研究はあまり見られないが, 道路のリニューア ル工事における養生中のコンクリートの振動の影響を 検討した事例では，振動の振幅が $1 \mathrm{~mm}$ 以下の場合， コンクリートの強度低下はなく，逆に強度が高くなる。 傾向にあるとの報告がある ${ }^{2}$. また，衝撃的な振動に 関しては，発波振動を対象として，100Hz で加速度 2000gal の振動を数十回加えた場合, 強度は高くなる傾 向にあるとの報告がある ${ }^{3)}$.

今回の計測では，セントル部の振動は変位で 5-10 $\mu \mathrm{m}$, 加速度は 1-3gal であり, 既往の研究よりも大幅 に小さいため, ベルトコンベヤの振動による養生中の コンクリートへの影響はないと言える。

\section{5. まとめ}

\section{（1）ベルトコンベヤの位置および支持方法}

覆工作業部は移動式支持台車により，ベルトコンベ ヤ稼動に関係なく覆工作業が可能になった．また，掘 削部も掘削側面よりチェーンおよびアンカーで吊るこ
とにより掘削作業に支障することなくベルトコンベヤ を配置する事ができた。覆工完了部，インバート部も ブラケットにより支持する事によりインバート作業に 支障なくベルトコンベヤを配置することができた，そ れぞれ作業箇所を支障なくベルトコンベヤを配置し， また支持することできて山岳工法のベルトコンベヤず り出し方式が可能になった.

（2）ベルトコンベヤ振動による覆エコンクリートヘ の影靁について

a ）既設の覆エコンクリート部

・ベルトコンベヤの振動は, 駆動部から発生している のではなく, ベルトコンベヤの走行およびべルトコ ンベヤのローラを掘削ズリが乗り越える時に振動が 発生している.

・ベルトコンベヤ稼働による動的荷重は910Nであり， 問題となるような動的荷重は発生していない.

・ベルトコンベヤ稼働時の覆工コンクリートの振動の 最大振幅は，以下のとおりである。

加速度：0. 003gal,

変位: $0.15 \mu \mathrm{m}$

ベルトコンベヤ停止時の 1.5 倍であった.

·振動により発生する覆工コンクリートの曲げ応力は, $4.15 \times 10^{-4} \mathrm{~N} / \mathrm{mm}^{2}$ と推定され, 材令 4 日の覆工コン クリート弓張り強度 $1.33 \mathrm{~N} / \mathrm{mm}^{2}$ と比較して非常に 小さく，振動の影響はない.

b）セントル部

・防振ゴム上および受け架台では $8.5 \mathrm{~Hz}, 18 \mathrm{~Hz}, 26.5 \mathrm{~Hz}$ に卓越振動数があり， $8.5 \mathrm{~Hz}$ は $1 / 6$ に $18 \mathrm{~Hz}$ は $1 / 10$ に低減しており，また変位最大值も $1 / 5$ に低減して おり，防振ゴムの効果が認められた。

・セントル部の振動は変位で 5 $10 \mu \mathrm{m}$, 加速度は 1 一-3gal であり, 既往の研究よりも大幅に小さくべル トコンベヤの振動による養生中のコンクリートへの 影響はないものと考えられた。

以上のように, ベルトコンベヤの振動は, 既設の覆 エコンクリートおよびセントル部において, 覆工コン クリートへの影響はないものと考えられた。

\section{6. おわりに}

山岳工法におけるベルトコンベヤずり出しシステム の導入において, 課題であったベルトコンべヤの位置, 支持方法またベルトコンベヤの振動が与える覆工の影 響について検討したが全く問題が無いことが分かった。 これらの方法により山岳工法におけるべルトコンベヤ 
ずり出し方式が可能となった.

\section{参考文献}

1）（社）土木学会：コンクリート標準示方書施工編, 1996.

2）山下宣博, 平野 実, 塚山隆一, 神垣典明: 養生中に継続
振動を受けるコンクリートの諸性質について，セメント・コ ンクリート, No.287, 1971.

3) 福留和人, 喜多達夫：若材令時コンクリートへの荷重お よび衝慗振動の影響，間組研究年報，1986，pp143-155

\title{
STUDY ON THE DEVELOPMENT OF BELT CONVEYOR MUCKING SYSTEM IN TUNNEL
}

\section{Yukio YOSHITOMI, Jun KAWAKAMI and Keisuke SHIMIZU}

\begin{abstract}
It is one of the most important problems in tunneling jobs to improve its working environment. Particularly in muck haulage, dump trucks have been used for mucking out, and this causes an inferior work environment in tunnels due to exhaust gas and dust produced by dump trucks. The authors developed the Continuous Conveyor System for the removal of spoil excavated by drilling+blasting method instead of dump truck transportation. Generally, excavation, concrete lining and invert work are concurrently executed in tunnel construction. The difficulty was to complete the conveyor system that would not disturb another works. This paper describes the arrangement and support measures of belt conveyor that were the most important point in this development and for applying this system to muck haulage in tunnels.
\end{abstract}

